\section{Quantification of Dissolved Organic Carbon at Very Low Levels in Natural Ice Samples by a UV-Induced Oxidation Method}

\author{
S. Preunkert ${ }^{\star} \dagger$, M. Legrand $\dagger$, P. Stricker $\neq$, \\ S. Bulat\$, I. Alekhina $\$$, J. R. Petit $\dagger$, \\ H. Hoffmann $\neq$, B. May $\neq$, and B. Jourdain $\dagger$ \\ Laboratoire de Glaciologie et Géophysique de l'Environnement \\ du Centre National de la Recherche Scientifique, St Martin \\ d'Hères, France, Institut fur Umweltphysik, Ruprecht \\ Karls-Universitat Heidelberg, Heidelberg, Germany, and \\ Petersburg Nuclear Physics Institute, Russian Academy of \\ Sciences, Leningrad Region, Gatchina, Russia
}

The study of chemical impurities trapped in solid precipitation and accumulated in polar ice sheets and high-elevation, midlatitude cold glaciers over the last several hundreds of years provides a unique way to reconstruct our changing atmosphere from the preindustrial era to the present day. Numerous ice core studies of inorganic species have already evaluated the effects of growing anthropogenic emissions

of $\mathrm{SO}_{2}$ or $\mathrm{NO}_{x}$ on the chemical composition of the atmosphere in various regions of the world. While it was recently shown that organic species dominate the atmospheric aerosol mass, the contribution of anthropogenic emissions to their budget remains poorly understood. The study of organics in ice is at the infancy stage, and it still is difficult to draw a consistent picture of the organic content of polar ice from sparse available data. A UV oxidation method and IR quantification of $\mathrm{CO}_{2}$ was optimized to obtain measurements of dissolved organic carbon content as low as a few ppbC. Stringent working conditions were defined to prevent contamination during the cleaningofice.Measurements in various ice corescorresponding to preindustrial times revealed dissolved organic carbon content of less than $10 \mathrm{ppbC}$ in Antarctica and up to $75 \mathrm{ppbC}$ in alpine ice.

\section{Introduction}

Ice cores extracted from polar ice sheets and high-elevation glaciers located at lower latitudes can provide information on past changes in atmospheric aerosol load and composition. In contrast to the inorganic fraction for which numerous detailed ice core records are available (see Legrand and Mayewski (1) for a review), information on the organic fraction of aerosol archived in ice is still very limited. Although carbonaceous matter is recognized as a major constituent of present-day atmospheric aerosol over the continents (see

\footnotetext{
*Corresponding author e-mail: preunkert@lgge.obs.ujfgrenoble.fr.

† Laboratoire de Glaciologie et Géophysique de l'Environnement du Centre National de la Recherche Scientifique.

‡ Ruprecht Karls-Universitat Heidelberg.

${ }^{\S}$ Russian Academy of Sciences.
}

Putaud et al. (2) and Legrand and Puxbaum (3) for Europe), there are still major gaps with respect to the sources. For instance, the relative contributions of natural (e.g., vegetation emissions) versus anthropogenic (e.g., fossil fuel combustions) sources for the present-day atmosphere as well as the variability of natural sources in the past are not well-known. This lack of knowledge motivates further investigation into the study of organic species in ice cores.

Until now, apart from methanesulfonate for which rather systematic investigations have been conducted to reconstruct past marine biogenic emissions of dimethylsulfur $(4,5)$, existing studies dealing with organic impurities in ice only focus on formaldehyde $(6,7)$, monocarboxylates (mainly formate and acetate (8)), C2-C5 dicarboxylates (9), and long chain (C14-C22) carboxylates (10). Apart from these studies of individual organic species, a few investigations were performed on the organic carbon content of snow and ice from Greenland, Antarctica, and the Alps. Given the difference of age (modern, preindustrial) and type (surface snow, firn, or ice) of investigated sample, of the deployed method (dissolved organic carbon, total organic carbon), and of the applied contamination control, it is still difficult to directly compare these sparse available data.

To address the lack of reliable data on organic content of ice cores, analyses have been performed at IUP (Institute fur Umweltphysik) to measure samples containing less than 10 ppbC of dissolved organic carbon. In a first attempt, an organic carbon analyzer (TOC Talk 1500) was adapted and deployed successfully to analyze several ice cores. However, this device did not allow the routine measurement of low level ice core samples, and thus another analyzer (Phoenix 8000) was purchased in collaboration with LGGE and extensively modified to gain reliable organic carbon measurements in the low ppb range. In the present paper, we present the analytical characteristics of this latter (modified) device. Further, we will detail the determination of low concentrations of organic material, which requires stringent precautions during ice core processing. Finally, the initial data gained by applying our method to determine dissolved organic carbon content of preindustrial ice extracted from Antarctica, Greenland, and midlatitude cold glaciers are reported here and the differences are briefly discussed.

\section{Experimental Section}

Setup of the Phoenix 8000 Analyzer. Apart from Fourier transform ion cyclotron resonance mass spectrometry coupled with electrospray ionization (11), the analysis of organic carbon in a melted ice sample includes the oxidation of the organic compounds to $\mathrm{CO}_{2}$, its separation from the liquid sample, and subsequent analysis. The conversion of organic compounds to $\mathrm{CO}_{2}$ can be achieved via either catalytic combustion, UV-induced oxidation, or combined UVinduced catalytic combustion (12). In most cases, the quantification of $\mathrm{CO}_{2}$ is performed by measuring IR absorption with a spectrometer after the $\mathrm{CO}_{2}$ is purged from the liquid sample into a clean carrier gas. In some cases, the quantification is performed by measuring the conductivity of a low conductivity water stream in which the $\mathrm{CO}_{2}$ of the sample has permeated through a membrane and by subsequent nontrivial conversion of the liquid conductivity values into a $\mathrm{CO}_{2}$ concentration (13).

With the aim to measure very low organic levels which characterize precipitation at very remote places, we have chosen a UV oxidation method, because the catalytic combustion method allows only sample volumes smaller than $2 \mathrm{~mL}$ on account of the induced cooling of the catalyst 
(14). Furthermore, the stability of the baseline, needed to reach a low detection limit, is difficult to attain with the combustion method because of the accumulation of nonvolatile residues in the reactor and subsequent release over time (15).

The device we used in this study to quantify organic content in low level liquid samples is based on a commercial system (Phoenix 8000) from the Teledyne Tekmar Company, which was modified to allow precise analysis of as small as possible sample volumes. The original operation software was discarded because of unnecessary measurement steps, and a custom-made Lab View program was used to gain control of the syringe pump and the electromagnetic valves, allowing the establishment of a completely user-controlled measurement sequence.

The modified device analyzes carbon by an automated two-step process. First, the liquid sample was introduced into an inorganic carbon sparger cell together with phosphoric acid at $21 \%$ by weight $(0.5 \mathrm{~mL}$ for a liquid sample of $4 \mathrm{~mL}$ ) prepared from a solution of $\mathrm{H}_{3} \mathrm{PO}_{4}$ at $85 \%$ by weight (J.T. Baker, Baker analyzed grad, reference 6024). The sample was continuously sparged with a carrier gas at a flow rate of $200 \mathrm{~mL}$ per min to drive off any inorganic carbon (dissolved carbon dioxide, carbonate, and bicarbonate). Next, the liquid sample was transferred from the inorganic carbon (IC) cell to a UV reactor cell where a UV lamp together with an oxidant oxidized the organic carbon to carbon dioxide. Carbon dioxide coming either from the IC cell or from the UV reactor was swept together with the carrier gas through a moisture control system and a halogen scrubber into a nondispersive infrared (NDIR) detector.

Using the original working conditions, we calibrated the device with reagent grade potassium hydrogen phthalate (Merck Certipur TOC standard solution at $1000 \mathrm{ppmC}$ ) as the organic calibration standard. The solution was diluted in ultrapure water into $500 \mathrm{~mL}$ glass bottles to obtain from 25 ppbC to 800 ppbC solutions. The slope of the calibration curve was found to significantly vary (up to $30 \%$ ) over the course of the day as seen in Figure S1, Supporting Information. It rapidly became clear that the calibration is very sensitive to room temperature changes (Figure S2, Supporting Information). Calibrations at detector temperatures between $38^{\circ} \mathrm{C}$ and $44^{\circ} \mathrm{C}$ indicated maximum stability at $44^{\circ} \mathrm{C}$. The temperature of the IR detector was therefore stabilized at this value.

In the premodified configuration, nitrogen was used as carrier gas, and an oxidant (ammonium persulfate) solution was added to the UV reactor in order to achieve complete oxidation even for some complex organic molecules such as humic acids. As discussed below, to reach blank values as low as possible, we avoided the addition of oxidant solution to the UV reactor. Instead we used synthetic air as carrier gas (instead of nitrogen) from which oxygen increases the oxidation efficiency. Under these working conditions, the efficiency of the oxidation relative to the potassium hydrogen phthalate was found to range from $85 \%$ to $125 \%$ for different organic molecule standards (Table S1, Supporting Information). This applies for organic species present at significant levels in natural ice such as monocarboxylic acids (lactic, acetic, glycolic, formic, glyoxylic), dicarboxylic acids (glutaric, malic, succinic, malonic, and oxalic), formaldehyde, and others not yet measured in ice but whose presence is expected including methanol, C2-C3 aldehydes (glyoxal, methyl glyoxal, and glycolaldehyde). For long chain polyacids that are also expected to be trapped in snow (humic-like substances, HULIS), the efficiency of the oxidation was found to be slightly low $80 \pm 2 \%$. It is generally accepted that UVinduced oxidation methods give low recoveries for particulate organic matter (16), especially for samples having a high particulate organic content. It is however possible that the
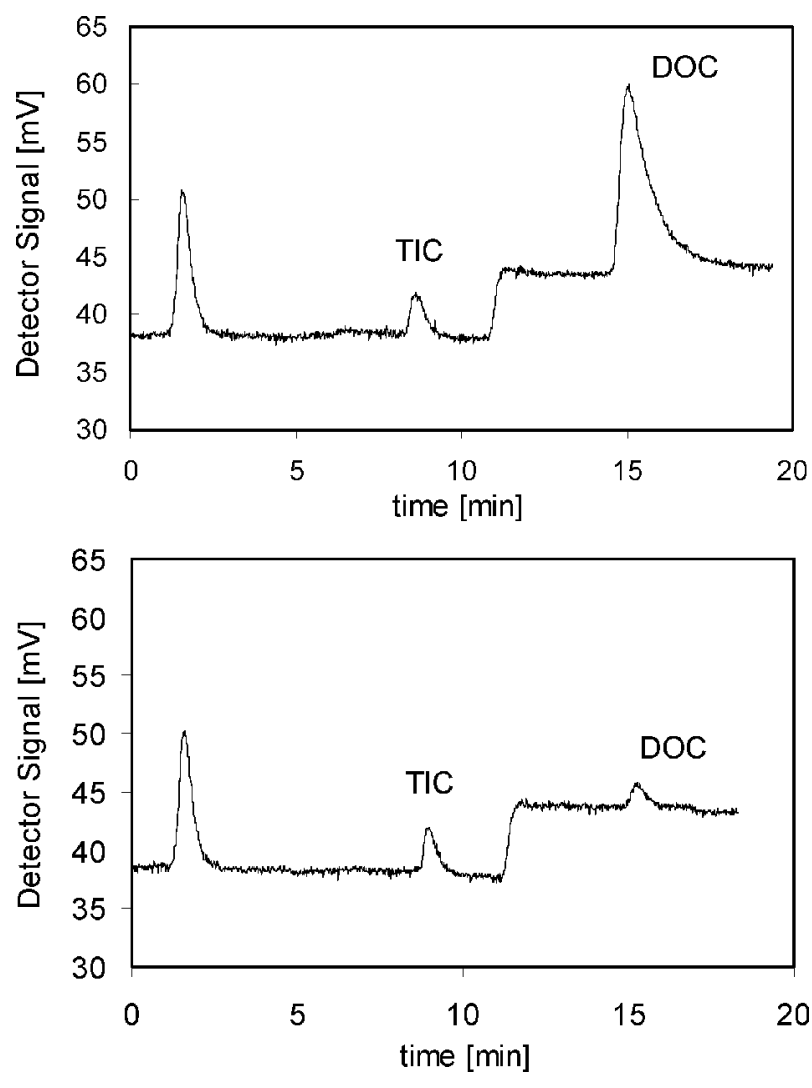

FIGURE 1. Typical records of the NDIR signal obtained over the course of analysis of a DOC sample $(330 \mathrm{ppbC}$, top) and of a blank sample (25 ppbC, bottom). The total inorganic carbon (TIC) and dissolved organic carbon (DOC) correspond to the peaks seen at 9 and $15 \mathrm{~min}$, respectively.

UV method is able to partly oxidize particulate matter present at low levels in melted ice samples. Because our attempts to quantify the recovery of particulate carbon in melted ice samples were unsuccessful due to contamination during filtering experiments, we report our data as dissolved organic carbon (DOC) rather than total organic carbon (TOC) values, the latter being more appropriate for data gained with combustion methods (16).

In the original configuration of the device, the amount of $\mathrm{CO}_{2}$ was quantified by integrating the $\mathrm{CO}_{2}$ peak area by using the raw NDIR signal without any baseline correction. With the objective to accurately determine DOC levels close to a few ppbC, the area of the $\mathrm{CO}_{2}$ peak was calculated by subtracting the background signal of the device. With the aim to accurately determine the baseline value just prior to the arrival of the $\mathrm{CO}_{2}$ sample peak, $4 \mathrm{~mL}$ of ultrapure water (Purelab Ultra MK2 analytic system commercialized by ELGA LabWater/VWS (UK) Ltd.), acidified similar to that of the sample, was injected into the IC sparger and the UV reactor, respectively, before each analysis of a real sample. Figure 1 depicts two examples of the sample run. The run starts by bringing ultrapure water into the IC sparger. After the IC content was degassed (peak seen at 1.5 min in Figure 1), the water was used to determine the IC baseline value, before being replaced by the sample (peak detected at 9 min; while the acidified ultrapure water is sent into the UV reactor, the $\mathrm{CO}_{2}$ signal corresponding to the DOC of ultrapure water is not seen in Figure 1 because the UV air flow is not yet sent to the NDIR detector). When all the IC content of the sample was degassed and the IC end-baseline determined, the detector was switched to the UV reactor gas stream, showing the baseline of DOC free ultrapure water and allowing the determination of the OC baseline value. The increase of the baseline from $38 \mathrm{mV}$ for IC to $44 \mathrm{mV}$ for OC is likely due to 


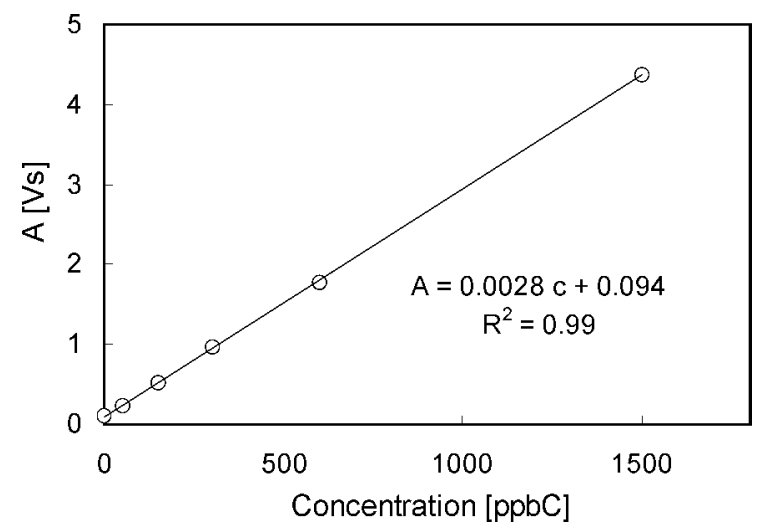

FIGURE 2. Typical calibration curve obtained with optimized working conditions.

trace organics in the synthetic air. Finally, the sample was transferred from the IC sparger to the UV reactor. After the DOC of the sample was degassed (peak seen at $15 \mathrm{~min}$ in Figure 1), the post sample peak baseline value was determined, the run was terminated, and all the liquid was discarded.

Using these modified working conditions, the typical calibration curve reported in Figure 2 was obtained. Calibrations were made regularly and showed a very stable value of the slope of the calibration curve (i.e., the response of the analyzer) over several months $(0.00301 \pm 0.0012$ in Vs $\mathrm{ppbC}^{-1}$ ). The $y$-intercept value of the calibration curve (i.e., the blank) is more variable than the value of the slope but typically ranges from 20 to $30 \mathrm{ppbC}$, thus being obviously higher than the expected DOC content of the ultrapure water $(<2 \mathrm{ppbC})$. This difference may correspond to a contamination of the water during its transfer or its stay in the UV reactor and/or a blank of the $\mathrm{H}_{3} \mathrm{PO}_{4}$ solution. This last possibility was tested by increasing the amount of added acid to the sample. The blank values (Bl in ppbC) were found to be linearly dependent on the added volume of acid ( $V$ in $\mathrm{mL}$ ) as $\mathrm{Bl}=9+31 \mathrm{~V}$. It can therefore be concluded that under our working conditions, two-thirds of the blank is related to the addition of the acid. These blank values are lower than those previously reported in the literature for this device (50 ppbC (17)). The UV oxidation coupled with a electrolytic conductometric method (13) has also been reported to give a blank value close to $50 \mathrm{ppbC}$. The addition of an oxidant solution to the Phoenix $8000 \mathrm{UV}$ reactor was found to increase the blank values. Indeed when $0.5 \mathrm{~mL}$ of a solution of ammonium persulfate at $5 \%$ was added, the blank values were typically enhanced by 50 ppbC. Because the aforementioned efficiency of the oxidation was found to be very good for all molecules of interest, no oxidant was added to the samples. Note that, during the whole run, the carrier gas was streamed through the IC sparger and the UV reactor.

Over the course of a day of sample analysis, at least three to five blanks were made showing a typical mean $( \pm 1 \sigma)$ of $25 \pm 1.5$ ppbC. This mean blank value was subtracted from the sample values. Taken as twice the variability of the blanks made over a day, the detection limit was found to be close to 3 to 5 ppbC. The typical uncertainty of the DOC determination, calculated by considering the uncertainty in the determination of the slope of the calibration curve and the variability of the blank value, is $4 \%$ for samples containing more than 50 ppbC. Because of the blank variability, the uncertainty becomes larger for lower DOC content samples, reaching $35 \%$ at the 5 ppbC level.

Contamination Controls. Numerous tests have shown that contact of samples with various plastic materials such as polytetrafluoroethylene (PTFE), perfluoroalkoxy (PFA),

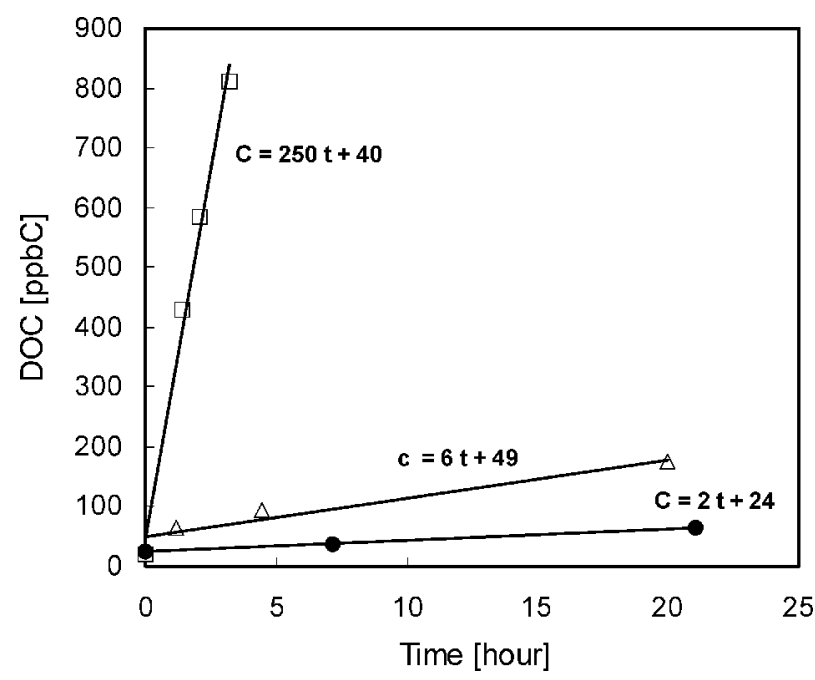

FIGURE 3. Changes over time in the DOC concentrations in $50 \mathrm{~mL}$ ultrapure water put in $100 \mathrm{~mL}$ glass vials kept open in the general purpose (open squares) and clean (open triangles) laboratories. Dark circles refer to ultrapure water in a glass vial kept closed in the general purpose lab. The area of the liquid sample in contact with air is $8 \mathrm{~cm}^{2}$.

polyethylene (PE), or polypropylene (PP) should be avoided for trace DOC analysis. Glass material was therefore chosen for the vials used to prepare standard solutions as well as the receptacle for the contaminated outer part of the ice (see below). The cleaning of all glass pieces was performed by rinsing them several times with ultrapure water. The efficiency of the cleaning procedure was controlled by checking the DOC value in a $5 \mathrm{~mL}$ ultrapure water volume poured into the glass device. When used for the first time, the efficiency of the cleaning can be enhanced by filling the glass device for one night with ultrapure water to which was added $1 \%$ by weight of persulfate.

It has already been demonstrated that measurements of organic ions such as formate or acetate present at low levels in ice can be erroneous because of dissolution of the atmospheric trace of formic and acetic acids in melted ice samples, if caution is not exercised during sample melting (18). This very likely applies to many other organic gaseous compounds present in laboratory air. To evaluate the magnitude of this potential contamination, glass bottles filled with ultrapure water were kept open over increasing time periods both in the clean room of the lab and in the "general purpose" room where the Phoenix device was set up. As seen in Figure 3a, contamination of $50 \mathrm{~mL}$ of ultrapure water put in open vials takes place at a rate of $250 \mathrm{ppbC}$ and 6.4 ppbC per hour in the general purpose and clean laboratories, respectively. In the general purpose lab we found a similar contamination rate when open vials were put under a clean bench, suggesting that the contamination comes from organic gas dissolution. The large contamination observed in the general purpose lab was likely caused by the presence of numerous bottles of organic reagent dedicated to various chemical determinations. Even in the clean lab, the contamination was significant, leading to a typical increase in concentration for a melted ice sample of $4 \mathrm{~mL}$ of water by 80 ppbC per hour. For the closed glass bottle kept in the general purpose lab, although far more limited than for an open bottle, the contamination of $4 \mathrm{~mL}$ of water reached about 25 ppbC per hour (instead of $\sim 3000$ ppbC per hour when kept open). With the aim to measure DOC content of remote precipitation, it is obvious that this source of contamination must be eliminated. To minimize this effect, a large volume of water $(500 \mathrm{~mL})$ was used to make low level standard solutions. Immediately after their preparation, the 
vial was closed for homogenization for a few minutes and analyzed within $10 \mathrm{~min}$ after preparation. Under these conditions, we could limit the contamination of the $500 \mathrm{~mL}$ standard sample to less than 1 ppbC.

Decontamination of Ice. The techniques deployed to extract ice cores from glaciers or ice sheets cause significant contamination with major (19) and minor (18) inorganic ions as evidenced by comparing the concentrations in the outer and inner parts of ice cores. As shown by Legrand et al. (20), the outer parts of the ice are contaminated, particularly with chloride, acetate, and all cations. With the aim to evaluate the magnitude of the contamination for DOC, we have analyzed the inner (see the detailed procedure below) and outer parts of a $50 \mathrm{~cm}$ long piece of ice core for ions as well as for DOC. It was found that the organic carbon level in the outer part exceeded that in the inner part by several hundreds of ppbC.

The contaminated outer part of ice cores can be removed either by shaving the ice using a lathe (20) or an electric plane device (21) or by melting the ice by rinsing it with clean water. Alternatively, the inner part of the core can also be recovered by recoring it with a melt head (22). We developed a special glass device in which pieces of ice can be washed with ultrapure water or kept melting. During sample melting, an inert gas atmosphere must be maintained inside the glass receptacle to prevent contact of the sample with the ambient air of the lab. If not, and given a contamination of 250 ppbC per hour observed in a $50 \mathrm{~mL}$ sample exposed to the ambient air of the lab (see above), a contamination by $500 \mathrm{ppbC}$ is expected after $10 \mathrm{~min}$ of exposure for a melted ice sample of $4 \mathrm{~mL}$.

The efficiency of the rinsing procedure in removing contamination was tested by checking DOC concentrations present in successive melted fractions. First, the outer part of the ice piece was removed with a saw in a cold room. The remaining piece of ice (typically a section of $2.5 \times 2.5 \mathrm{~cm}$ and a length of $5 \mathrm{~cm}$ ) was stored for $1 \mathrm{~h}$ in a refrigerator at $0{ }^{\circ} \mathrm{C}$ in order to avoid formation of cracks during subsequent rinsing at ambient temperature. After removal of $30 \%$ of the ice by rinsing it with ultrapure water at $20^{\circ} \mathrm{C}$, the sample was then placed in the glass receptacle and slowly melted. Successively $5 \mathrm{~mL}$ meltwater fractions were directly sucked from the bottom of the receptacle into the Phoenix device. During the whole procedure, high purity nitrogen (N60) streamed through the glass receptacle at a rate of $400 \mathrm{~mL}$ per minute. A typical example of the results is reported in Figure 4 , clearly showing a rapid decrease of concentrations from the outside to the inside of the ice core, the inner part (less than $50 \%$ of the sample) being free of DOC as well as organic ion (e.g., formate and acetate) contamination.

On this basis, and with the aim to minimize the sample decontamination time, the following procedure was applied routinely. After its storage for $1-2 \mathrm{~h}$ at $0{ }^{\circ} \mathrm{C}$, the sample was rinsed with ultrapure water and then put in the receptacle, which was filled with ultrapure water (around $400 \mathrm{~mL}$ ). Then the receptacle was emptied in a way that more than $50 \%$ of the initial volume (see Figure 4 ) of ice was melted. Note that with this procedure we avoided any contact of the ice sample with the contaminated ambient air which was temporally introduced inside the receptacle at its opening. After complete melting of the remaining ice, the liquid was transferred to the Phoenix 8000.

DOC Measurements in Various Preindustrial Ices: Atmospheric Implications. Using working conditions detailed above, we investigated the DOC content of preindustrial ice extracted from several Antarctic sites, the Greenland site of Summit, and the high-elevation, midlatitude Alpine site of the Mt. Blanc summit glacier (Table 1). The dating of Antarctic ice cores has been estimated by Parennin et al. (23) for Vostok, by Delmas et al. (24) for the South Pole, and by
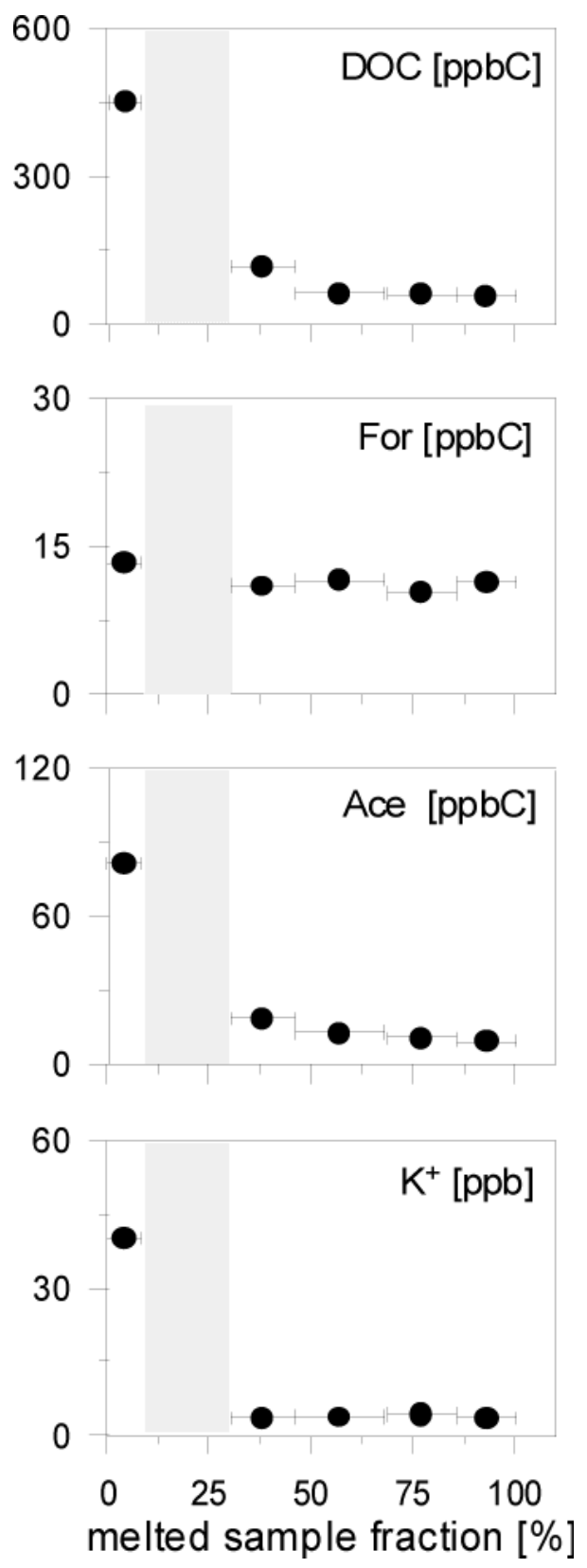

FIGURE 4. Decontamination of a piece of ice from a winter layer (1978/79) at Mt. Blanc by "wash-melting" with ultrapure water. The gray area refers to the ice which was rinsed with ultrapure water prior to introduction to the glass device. The last four fractions correspond to melted ice volumes of 5-6 m L (i.e., a removal of 3 to $4 \mathrm{~mm}$ ice thickness).

Ciais et al. (25) for D47. For the Antarctic ice samples, DOC values reported in Table 1 are not seasonally resolved and can be considered as annual means. The age of pieces of ice from Summit and Mt. Blanc were estimated by Clausen et al. (26) and Preunkert et al. (27), respectively. As depicted in Figure 5, DOC ice concentrations of the Summit ice layers are seasonally resolved with a minimum of sodium corresponding to the winter season at that site (1). Pieces of ice from Mt. Blanc are also seasonally resolved (27).

As seen in Table 1, the investigated Greenland and Antarctica ices correspond to preindustrial times. In the Alps, the ice corresponds to the 1925-1935 decade, a period over which human activities had already started to disturb the preindustrial atmosphere. The DOC content of summer ice layers in the Alps was previously investigated by using a UVinduced method for ice deposited prior to 1850 (19). The 
TABLE 1. DOC Concentrations Observed in Preindustrial Ice Extracted from Antarctica, Greenland, and the Alps $a$

\begin{tabular}{lllc}
\multicolumn{1}{c}{ sites } & \multicolumn{1}{c}{ Iocation (elevation asl) } & age & DoC in ppbC \\
Vostok & East Antarctica $(3488 \mathrm{~m})$ & $9970 \mathrm{BP}$ & $5.2 \pm 1.7$ \\
D47 & East Antarctica $(1500 \mathrm{~m})$ & $9970 \mathrm{BP}$ & $1.7 \pm 1.7$ \\
South Pole & Central Antarctica $(2850 \mathrm{~m})$ & $1010 \mathrm{BP}$ & 7.4 \\
Summit & Central Greenland $(3240 \mathrm{~m})$ & $1020 \mathrm{AD}$ & $10(\mathrm{~W})$ to $40(\mathrm{~S})$ \\
Mt. Blanc & French Alps $(4250 \mathrm{~m})$ & $1925-1936 \mathrm{AD}$ & $\mathbf{1}$ \\
\end{tabular}
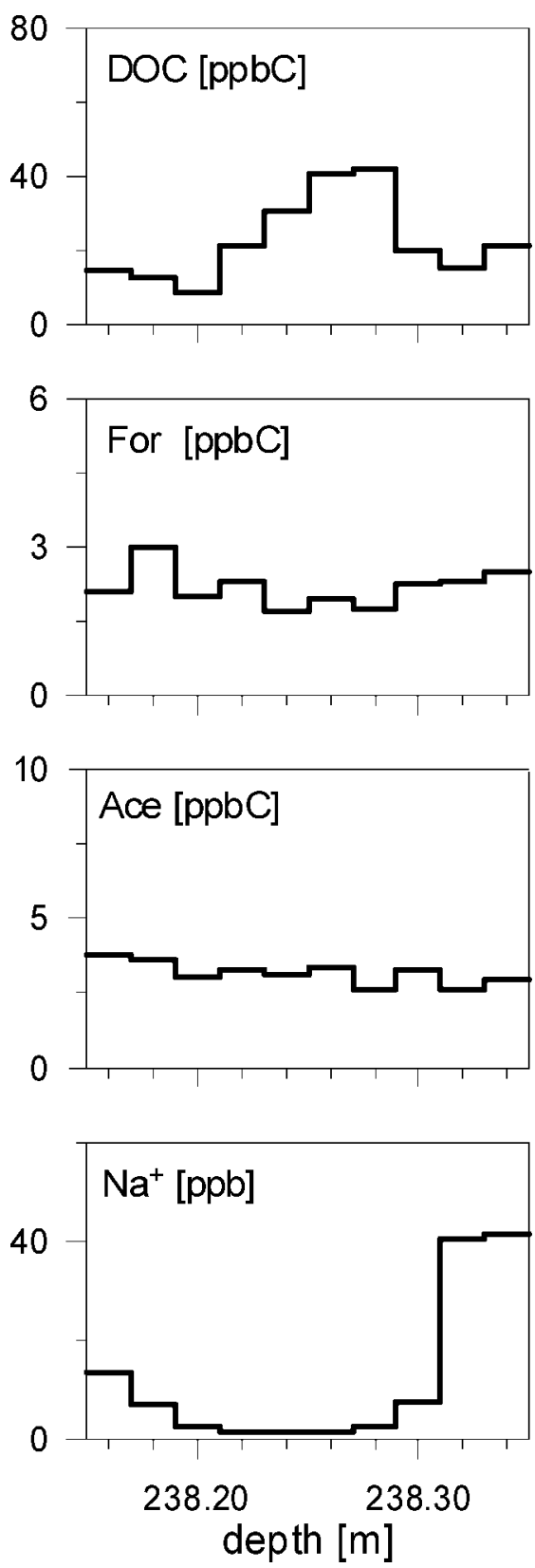

FIGURE 5. Concentrations of DOC, formate (For), acetate (Ac), and sodium $(\mathrm{Na}+)$ along a $20 \mathrm{~cm}$ long piece of ice extracted from Summit in Greenland and dated to 1020 AD. Note that the DOC concentrations are maxima when sodium levels are low (i.e., in summer).

authors reported a mean value of $130 \mathrm{ppbC}$ without correcting it from the blank ( $30 \mathrm{ppbC}$ ), both for the 1925-1936 years and prior to 1850 . The value we observed in summer ice over the 1925-1936 decade ( 100 ppbC, Table 1$)$ therefore seems to be representative of the preindustrial level in the Alps. Note that the comparison between the two data sets would not have been impacted by a possible difference in efficiency of the two UV methods for oxidizing particulate organics because investigations of water-insoluble organic carbon (WinOC) indicate a rather small WinOC content with respect to the DOC content, $26 \mathrm{ppbC}$ compared to $100 \mathrm{ppbC}$ in the 1925-1935 summer layers (19).

Annual mean DOC concentrations in ice corresponding to preindustrial time rise from $\sim 5 \mathrm{ppbC}$ in Antarctica to 25 ppbC in Greenland and to $75 \mathrm{ppbC}$ in the Alps. As discussed by Legrand et al. (19), the DOC content of ice accounts for water-soluble organic aerosol as well as organic gases which are water-soluble. The authors demonstrated that in summer ice layers in the Alps, monocarboxylic acids (mainly formic and acetic) likely represent most of the water-soluble organic gases, accounting for the $27 \pm 7 \%$ of the DOC levels. As shown in Figure 5, in Greenland ice, formic and acetic acids together account for 6 ppbC (i.e., $30 \%$ of the DOC level). Thus, it can be assumed that about two-thirds of the DOC content of Greenland and Alpine ice are related to water-soluble organic aerosol. Therefore, the observed increasing level of DOC in preindustrial ice from Antarctica to Greenland and the Alps is in consistent qualitative agreement with the fact that the dominant natural sources of organic aerosol (biomass burning and vegetation emissions) are located over these continents. The seasonal cycle of the DOC level is characterized by a summer maximum in both Greenland and Alpine preindustrial ice (Table 1). That would suggest an important role of vegetation emissions in the organic aerosol budget both in Europe and in the boreal zone because these emissions mainly occur in summer. Such a dominant role of vegetation emissions in the organic aerosol budget in summer at high-elevation European sites has been established for the present-day atmosphere (28) and would be even more true for preindustrial times.

\section{Acknowledgments}

We thank D. Wagenbach, S. Greilich, and M. Schock from the IUP, for their analytical efforts over the past 11 years in contributing to the routine measurement of low level DOC samples. The work was partly supported by European Commission through the Project CARBOSOL (EVK2-2001113) and by the ongoing CNRS-DFG French-German project "Secondary organic aerosol production in the lower free troposphere over western Europe". We thank the two anonymous reviewers for their fruitful comments. We are also very grateful to C. Legrand for the sometimes unconventional inspiration she gave us to help overcome serious contamination problems.

\section{Supporting Information Available}

The oxidation efficiencies of different organic species relative to the potassium hydrogen phthalate standard are reported in Table S1; calibration curves over the course of a day when the temperature of the IR detector was not stabilized (Figure S1) as well as showing temperature dependency (Figure S2). This material is available free of charge via the Internet at http://pubs.acs.org. 


\section{Literature}

(1) Legrand, M.; Mayewski, P. Glaciochemistry of polar ice cores: A review. Rev. Geophys. 1997, 35, 219-243.

(2) Putaud, J.-P.; Raes, F.; Van Dingenen, R.; Brueggemann, E.; Facchini, M. C.; Decesari, S.; Fuzzi, S.; Gehrig, R.; Hueglin, C.; Laj, P.; Lorbeer, G.; Maenhaut, W.; Mihalopoulos, N.; Mueller, K.; Querol, X.; Rodriguez, S.; Wiedensohler, A. A European aerosol phenomenology-2: chemical characteristics of particulate matter at kerbside, urban, rural and background sites in Europe. Atmos. Environ. 2004, 38, 2579-2595.

(3) Legrand, M.; Puxbaum, H. Summary of the CARBOSOL project: Present and Retrospective State of Organic versus Inorganic Aerosol over Europe. J. Geophys. Res. 2007, 112, D23S01. DOI: 10.1029/2006JD008271.

(4) Legrand, M.; Feniet-Saigne, C.; Saltzman, E. S.; Germain, C.; Barkov, N. I.; Petrov, V. N. An ice core record of oceanic emissions of dimethylsulfide during the last climatic cycle. Nature 1991, 350, 144-146.

(5) Wolff, E. W.; Fischer, H.; Fundel, F.; Ruth, U.; Twarloh, B.; Littot, G. C.; Mulvaney, R.; Röthlisberger, R.; De Angelis, M.; Boutron, C. F.; Hansson, M.; Jonsell, U.; Hutterli, M. A.; Lambert, F.; Kaufmann, P.; Stauffer, B.; Stocker, T. F.; Steffensen, J. P.; Bigler, M.; Siggaard-Andersen, M. L.; Udisti, R.; Becagli, S.; Castellano, E.; Severi, M.; Wagenbach, D.; Barbante, C.; Gabrielli, P.; Gaspari, V.Southern ocean sea-ice extent productivity and iron flux over the past eight glacial cycles. Nature 2006, 440, 491-496.

(6) Staffelbach, T.; Neftel, A.; Stauffer, B.; Jacob, D. A record of the atmospheric methane sink from formaldehyde in polar ice cores. Nature 1991, 349, 603-605.

(7) Hutterli, M.; McConnell, J. R.; Bales, R.; Steward, R. Sensitivity of hydrogen peroxide $\left(\mathrm{H}_{2} \mathrm{O}_{2}\right)$ and formaldehyde ( $\left.\mathrm{HCHO}\right)$ preservation in snow to changing environmental conditions: Implications for ice core records. J. Geophys. Res. 2003, 108. DOI: $10.1029 / 2002 J D 002528$.

(8) Legrand, M.; De Angelis, M. Origins and variations of light carboxylic acids in polar precipitation. J. Geophys. Res. 1995, 100, 1445-1462.

(9) Legrand, M.; Preunkert, S.; Schock, M.; Cerqueira, M.; KasperGiebl, A.; Afonso, J.; Pio, C.; Gelencsér, A.; DombrowskiEtchevers, I. Major 20th century changes of carbonaceous aerosol components (EC, WinOC, DOC, HULIS, carboxylic acids, and cellulose) derived from Alpine ice cores. J. Geophys. Res. 2007, 112, D23S11. DOI: 10.1029/2006JD008080.

(10) Kawamura, K.; Suzuki, I.; Fujii, Y.; Watanabe, O. Ice core record of fatty acids over the past 450 years in Greenland. Geophys. Res. Lett. 1996, 23 (19), 2665-2668.

(11) Grannas, A.; Hockaday, C.; Hatcher, P.; Thompson, L.; MosleyThompson, E. New revelations on the nature of organic matter in ice cores. J. Geophys. Res. 2006, 111, D04304. DOI: 10.1029/ 2005JD006251.

(12) Golimowski, J.; Golimowska, K. UV-photooxidation as pretreatment step in inorganic analysis of environmental samples. Anal. Chem. Acta 1996, 325, 111-123.

(13) Federer, U.; Kaufmann, P. R.; Hutterli, M.; Schüpbach, S.; Stocker, T. F. Continuous flow analysis of total organic carbon in polar ice cores. Environ. Sci. Technol. 2008, 42, 8039-8043.
(14) Wallace, B.; Purcell, M. Minimizing your instrument background for total organic carbon analysis. Application note June 2003 (Tekmar).

(15) Stevens, R. How to gain reliable, fast, precise, and accurate TOC results from purified water, water for injection, ultra-high purity water, and clean in place. Application note January 2004 (Tekmar).

(16) Booth, R.; Furlong, J.; Wallace, B. Selection of a TOC analyzer: Analytical considerations. Application note Fall 1998 (Tekmar).

(17) Wallace, B. European Pharmacopoeia Method 2.2.44: Total Organic Carbon (TOC) analysis for pharmaceutical water using the Phoenix 8000 UV-persulfate TOC analyzer. Application note June 2003 (Tekmar)

(18) Saigne, C.; Kirchner, S.; Legrand, M. Ion-chromatographic measurements of ammonium, fluoride, acetate, formate, and methanesulphonate ions at very low levels in Antarctic ice. Anal. Chim. Acta 1987, 203, 11-21.

(19) Legrand, M.; De Angelis, M.; Delmas, R. Ion chromatographic determination of common ions at ultratrace levels in Antarctic snow and ice. Anal. Chim. Acta 1984, 156, 181-192.

(20) Legrand, M.; De Angelis, M.; Maupetit, F. In the field investigation of major and minor ions along Summit (Central Greenland) ice cores using ion chromatography. J. Chromatogr. 1993, 640, 251258.

(21) Fischer, H.; Wagenbach, D.; Kipfstuhl, J. Sulfate and nitrate firn concentrations on the Greenland ice sheet. J. Geophys. Res. 1998, 103, 21927-21934.

(22) Kaufmann, P.; Federer, U.; Hutterli, M.; Bigler, M.; Schüpbach, S.; Ruth, U.; Stocker, T. F. A new continuous flow analysis (CFA) system for high-resolution field measurements on ice cores. Environ. Sci. Technol. 2008, 42, 8044-8050.

(23) Parrenin, F.; Barnola, J.-M.; Beer, J.; Blunier, T.; Castellano, E.; Chappellaz, J.; Dreyfus, G.; Fischer, H.; Fujita, J. J. S.; Kawamura, K.; Lemieux-Dudon, B.; Loulergue, L.; Masson-Delmotte, V.; Narcisi, B.; Petit, J.-R.; Raisbeck, G.; Raynaud, D.; Ruth, U.; Schwander, J.; Severi, M.; Spahni, R.; Steffensen, J. P.; Svensson, A.; Udisti, R.; Waelbroeck, C.; Wolff, E. The EDC3 chronology for the EPICA Dome C ice core. Clim. Past 2007, 3, 485-497.

(24) Delmas, R. J.; Kirchner, S.; Palais, J.; Petit, J.-R. 1000 years of explosive volcanism recorded at the South Pole. Tellus 1992, 44 B, 335-350.

(25) Ciais, P.; Jouzel, J.; Petit, J. R.; White, J. W. C. Holocene temperature variations inferred from six Antarctic ice cores. Ann. Glaciol. 1994, 20, 427-436.

(26) Clausen, H. B.; Hammer, C. U.; Hvidberg, C. D.; Dahl-Jensen, D.; Kipfstuhl, J.; Legrand, M. A comparison of the volcanic records over the past 4000 years from the Greenland Ice Core Project and Dye 3 Greenland ice cores. J. Geophys. Res. 1997, 102, 26707-26723.

(27) Preunkert, S.; Wagenbach, D.; Legrand, M.; Vincent, C. Col du Dôme (Mt Blanc Massif, French Alps) suitability for ice core studies in relation with past atmospheric chemistry over Europe. Tellus 2000, 59, 993-1012.

(28) Gelencsér, A.; May, B.; Simpson, D.; Sánchez-Ochoa, A.; KasperGiebl, A.; Puxbaum, H.; Caseiro, A.; Pio, C.; Legrand, M. Source apportionment of PM2.5 organic aerosol over Europe: Primary/ secondary, natural/anthropogenic, and fossil/biogenic origin. J. Geophys. Res. 2007, 112, D23S04. DOI: 10.1029/2006JD008094. 